\title{
Recurrent genital candidosis and iron metabolism
}

\author{
FIONA DAVIDSON AND J. P. HAYES \\ From Westminster Hospital, London \\ SONAY HUSSEIN \\ From the Department of Haematology, Royal Free Hospital, London
}

SUMMARY It was thought possible that recurrent genital candidosis, like chronic mucocutaneous candidiasis, might be related to abnormalities in iron metabolism. Haemoglobin, serum iron, and serum ferritin levels of patients with recurrent genital candidosis were compared with those of patients who harboured yeasts but had no history of 'thrush', and with a control group of patients with no evidence of yeasts or history of 'thrush'. The mean haemoglobin level in patients with recurrent genital candidosis was significantly lower than in the control group $(P<0.05)$ but it was thought that this difference did not have much practical meaning. There was no significant difference in the serum iron and serum ferritin levels between the three groups.

\section{Introduction}

Candida infection of the genital mucosa and anogenital skin in women is a well-known and common condition (Oriel et al., 1972; Hurley et al., 1973; Hilton and Warnock, 1975; Willmott, 1975). It is enhanced by antibiotics and immunosuppressive drugs and by certain conditions such as pregnancy and diabetes mellitus. There is, however, a group of women in whom no obvious provoking cause can be found. These patients have recurring attacks of yeast infection at varying intervals, sometimes over many years, causing distress to themselves and their sexual partners, frequently upsetting their marriages. Higgs and Wells (1972) noted that a group of patients with chronic mucocutaneous candidiasis had iron deficiency as judged by low serum iron and decreased marrow iron stores. They considered that a disturbance in iron metabolism might be an aetiological factor in these patients. It was decided to investigate the iron status of patients with recurrent genital candidosis of unknown aetiology, using haemoglobin, serum iron, and serum ferritin levels. The last is a relatively new and reliable method of assessing iron storage status (Jacobs and Worwood, 1975).

\footnotetext{
Address for reprints: Dr F. Davidson, Senior Registrar, Department of Genitourinary Medicine, Westminster Hospital, Dean Ryle Street, Horseferry Road, London SW1P 2AP
}

Received for publication 8 October 1976

\section{Subjects and methods}

One hundred women attending the Clinic for Sexually Transmitted Diseases at the Westminster Hospital between April 1975 and February 1976 were investigated. They were divided into three groups (Table) according to the mycological investigation. Oral, vaginal, and rectal samples were taken with sponge swabs (Oates et al., 1971); smears were stained with Gram's stain and the swabs cultured for yeasts in Feinberg-Whittington medium for 48 hours at a temperature of $37^{\circ} \mathrm{C}$.

Group 1, the recurrent genital candidosis group, comprised 43 patients with a history of recurrent attacks of 'thrush' sufficient to cause distress. During the period of our contact with these patients either before, during, or after investigation, 37 of them had three or more culturally-proved clinical attacks of yeast infection; 16 of these 37 had six attacks or more. The remaining six patients all had histories of more than two years with repeated treatments elsewhere, three of these patients had two proved clinical attacks at our clinic, and the remaining three had one attack.

Group 2, the non-recurrent group, comprised 31 patients with evidence of yeasts in either the mouth, vagina, or rectum but with no history of 'thrush'. Some of these patients had other infections.

Group 3, the control group, comprised 26 patients with no evidence of yeast infection at any site and no history of 'thrush'. Some of these patients had other genital infections. 
Table Results for the three groups

\begin{tabular}{|c|c|c|c|}
\hline & $\begin{array}{l}\text { Group } 1 \\
\text { (Recurrent } \\
\text { candidosis) }\end{array}$ & $\begin{array}{l}\text { Group } 2 \\
\text { (Non- } \\
\text { recurrent } \\
\text { candidosis) }\end{array}$ & $\begin{array}{l}\text { Group } 3 \\
\text { (Controls) }\end{array}$ \\
\hline $\begin{array}{l}\text { No. in group } \\
\text { Age (years) } \\
\text { range } \\
\text { No. taking }\end{array}$ & $\begin{array}{l}43 \\
27 \cdot 4 \\
(19-46)\end{array}$ & $\begin{array}{l}31 \\
27 \cdot 0 \\
(16-45)\end{array}$ & $\begin{array}{l}26 \\
26 \cdot 5 \\
(19-40)\end{array}$ \\
\hline $\begin{array}{l}\text { contraceptive pill } \\
\%\end{array}$ & $\begin{array}{l}31 / 39 \\
79\end{array}$ & $\begin{array}{l}14 / 28 \\
50\end{array}$ & $\begin{array}{l}17 / 26 \\
65\end{array}$ \\
\hline $\begin{array}{l}\text { Serum ferritin } \\
(\mu \mathrm{g} / \mathrm{l})\end{array}$ & & & \\
\hline $\begin{array}{l}\text { mean } \\
\text { range } \\
\text { SD }\end{array}$ & $\begin{array}{l}86 \cdot 5 \\
(6-205) \\
52 \cdot 7\end{array}$ & $\begin{array}{l}79 \cdot 8 \\
(6-250) \\
57 \cdot 1\end{array}$ & $\begin{array}{l}78 \cdot 0 \\
(14-220) \\
56 \cdot 8\end{array}$ \\
\hline $\begin{array}{l}\text { Serum iron }(\mu \mathrm{mol} / 1) \\
\text { mean } \\
\text { range } \\
\text { SD }\end{array}$ & $\begin{array}{l}19 \cdot 1 \\
(5 \cdot 1-32 \cdot 9) \\
6 \cdot 6\end{array}$ & $\begin{array}{l}22 \cdot 4 \\
(11 \cdot 5-44 \cdot 6) \\
8 \cdot 6\end{array}$ & $\begin{array}{l}22 \cdot 0 \\
(6 \cdot 4-39 \cdot 3) \\
9 \cdot 0\end{array}$ \\
\hline $\begin{array}{l}\text { Haemoglobin }(g / d) \\
\text { mean } \\
\text { range } \\
\text { SD }\end{array}$ & $\begin{array}{l}13 \cdot 0 \\
(9 \cdot 4-14 \cdot 7) \\
1 \cdot 0\end{array}$ & $\begin{array}{l}13 \cdot 4 \\
(11 \cdot 0-14 \cdot 9) \\
1 \cdot 0\end{array}$ & $\begin{array}{l}13 \cdot 5 \\
(11 \cdot 9-15 \cdot 2) \\
0 \cdot 87\end{array}$ \\
\hline
\end{tabular}

Statistical tests The haemoglobin, serum iron, and serum ferritin levels in all three groups were compared by Student's $t$ test for significance of difference between the means. Only when the haemoglobin in group 1 was compared with that in group 3 was a statistically significant difference obtained $(t=2.02 \quad 0.05>\mathrm{P}>0.025)$. As the serum ferritin has a $\log$ normal distribution, the logarithmic values were compared by Student's $t$ test of the significance of difference between the $\log$ means and the log standard deviations. No significant difference was found ( $t>0.6$ in all three comparisons).

Haemoglobin, blood film, serum iron, and serum ferritin levels were estimated on all patients. Twenty-two patients of group 1 who had an acute attack at the time of the investigation were compared as a group with the other two groups.

The haematological parameters were measured by the Coulter $\mathbf{S}$ automatic cell counter. The serum iron levels were estimated by a biochmedical spectrophotometric method (Weippl et al., 1973)*, and the serum ferritin levels by the immunoradiometric assay method described by Addison et al. (1972).

\section{Results}

The average ages in each group were similar, but more patients in group 1 were taking oral contraceptives (Table). The mean haemoglobin level in group 1 was significantly lower than in group 3 $(P<0.05)$, but there was no significant difference in the haemoglobin levels between group 1 and group 2 , or between group 2 and group 3. There was also no significant difference between serum iron and ferritin levels in the three groups (Table). The mean serum ferritin level $(64.9 \mu \mathrm{g} / \mathrm{l})$ of 22 patients with acute attack of candidosis in group 1 was similar to the means of group $2(79.8 \mu \mathrm{g} / \mathrm{l})$ and group $3(78.0 \mu \mathrm{g} / \mathrm{l})$.

*(Kit manufactured by Boehringer, Mannheim GMBH 'Iron without deproteinization'. Cat. no.: 15895).
Two patients from group 1 had haemoglobin levels of $9.4 \mathrm{~g} / \mathrm{dl}$ and $10.5 \mathrm{~g} / \mathrm{dl}$ and two patients from group $2 \mathrm{had}$ haemoglobin levels of $11.0 \mathrm{~g} / \mathrm{dl}$ and $11.4 \mathrm{~g} / \mathrm{dl}$. Only one of these patients, who was in group 1, had a microcytic hypochromic anaemia with low serum ferritin and low serum iron levels. This patient was investigated for blood loss but no obvious cause could be found. It may be relevant that she had an intrauterine coil and her menstrual loss was heavy. The other three patients had normal serum iron and ferritin levels and their blood films showed normocytic and normochronic red cells. A further two patients from group 1 and one patient from group 2 had low serum ferritin levels $(<14 \mu \mathrm{g} / \mathrm{l})$ without anaemia. One of these patients from group 1 had a serum ferritin level of $6 \mu \mathrm{g} / \mathrm{l}$ and a haemoglobin level of $12.6 \mathrm{~g} / \mathrm{dl}$, but her blood film appeared normal. The investigations were repeated six months later; the serum ferritin level was $30 \mu \mathrm{g} / 1$ and the haemoglobin $13.8 \mathrm{~g} / \mathrm{dl}$.

There was no correlation between the serum iron and serum ferritin levels, as Addison et al. (1972) found ( $r=0.07$ for group $1, r=0.13$ for groups 2 and 3 combined).

\section{Discussion}

Iron deficiency has often been found to be associated with chronic infections. Higgs and Wells (1972) suggested that many patients with chronic mucocutaneous candidiasis had latent iron deficiency-that is, low serum iron values, normal or raised iron binding capacity, and deficiencies in iron stores but normal haemoglobin levels. They thought the condition might have an underlying genetic factor, and this has aroused great interest.

Fielding (1975), in a review of the relationship of clinical symptoms and iron deficiency, stated that the work of Higgs and Wells (1972) "has perhaps done more to focus attention on the complex relation of iron metabolism to infection than any other study'. Jacobs (1975) commented on their finding that iron treatment of these patients was effective even when coexisting immunological defects remained unchanged. We wondered whether similar defects might be found in patients with recurrent genital candidosis of unknown aetiology.

The mean haemoglobin level in group 1 was significantly lower than that in group $3(0.05>P>$ 0.025 ). This difference was probably due to the presence in group 1 of two patients with very low haemoglobin levels of $9.4 \mathrm{~g} / \mathrm{dl}$ and $10.5 \mathrm{~g} / \mathrm{dl}$, and although the result is statistically significant it is not thought to have much practical meaning.

Serum ferritin levels were used to assess iron storage in patients with recurrent genital candidosis. The concentration of serum ferritin correlates well 
with iron stores measured by phlebotomy (Walters et al., 1973); low levels of serum ferritin in iron deficiency and marked elevation in iron overload have been observed (Jacobs et al., 1972). The test is useful in detecting iron deficiency in patients with anaemia and chronic disorders who may have low serum iron concentrations but normal or increased iron stores (Bentley and Williams, 1974).

However, there was no significant difference found between serum iron or serum ferritin levels in the patients with recurrent genital candidosis either during an acute attack or between attacks when compared with either of the other two groups.

Only one patient from group 1 showed an iron deficiency anaemia with a low serum iron and low serum ferritin level.

Thus, although a disturbance in iron metabolism has been found in chronic mucocutaneous candidiasis, our results indicate this is not an aetiological factor in patients with recurrent genital candidosis, as judged by iron stores measured by serum iron and serum ferritin levels. It seems that these two clinical conditions are not as similar as they superficially appear.

We would like to thank Dr J. K. Oates for his permission to investigate these patients under his care, Mr Richardson and his colleagues in the Sexually Transmitted Diseases Department and Mr Pramod Pendarkher in the Haematology Department at the Westminster Hospital, and Martine Laulicht in the Haematology Department at the Royal Free Hospital for their technical assistance.

\section{References}

Addison, G. M., Beamish, M. R., Hales, C. N., Hodgkins, M., Jacobs, A., and Llewellin, P. (1972). An immunoradiometric assay for ferritin in the serum of normal subjects and patients with iron deficiency and iron overload. Journal of Clinical Pathology, 25, 326-329.

Bentley, D. P., and Williams, P. (1974). Serum ferritin concentration as an index of storage iron in rheumatoid arthritis. Journal of Clinical Pathology, 27, 786-788.

Fielding, J. (1975). Clinical symptoms and syndromes of iron deficiency. In Iron Metabolism and its Disorders. Proceedings of the Third Workshop Conference Hoechst Schloss Reisenburg, 6-9 April 1975, p.130. Edited by H. Kief. Elsevier: New York.

Higgs, J., and Wells, R. S. (1972). Chronic mucocutaneous candidiasis: associated abnormalities of iron metabolism. British Journal of Dermatology, 86, Supplement 8, 88-102.

Hilton, A. L., and Warnock, D. W. (1975). Vaginal candidiasis and the role of the digestive tract as a source of infection. British Journal of Obstetrics and Gynaecology, 82, 922-926.

Hurley, R., Leask, B. G. S., Faktor, J. A., and de Fonseka, C. I. (1973). Incidence and distribution of yeast species and of trichomonas vaginalis in the vagina of pregnant women. Journal of Obstetrics and Gynaecology of the British Commonwealth, 80, 252-257.

Jacobs, A. (1975). Iron deficiency effects on tissues and enzymes. In Iron Metabolism and its Disorders. Proceedings of the Third Workshop Conference Hoechst Schloss Reisenburg, 6-9 April 1975, p.139. Edited by $\mathrm{H}$. Kief. Elsevier: New York.

Jacobs, A., Miller, F., Worwood, M., Beamish, M. R., and Wardrop, C. A. (1972). Ferritin in the serum of normal subjects and patients with iron deficiency and iron overload. British Medical Journal, 4, 206-208.

Jacobs, A., and Worwood, M. (1975). Ferritin in serum, clinical and biochemical implications. New England Journal of Medicine, 292, 951-956.

Oates, J. K., Selwyn, S., and Breach, M. R. (1971). Polyester sponge swabs to facilitate examination for genital infection in women. British Journal of Venereal Diseases, 47, 289-292.

Oriel, J. D., Partridge, B. M., Denny, M. J., and Coleman, J. C. (1972). Genital yeast infections. British Medical Journal, 4, 761-764.

Walters, G. O., Miller, F. M., and Worwood, M. (1973). Serum ferritin concentration and iron stores in normal subjects. Journal of Clinical Pathology, 26, 770-772.

Weippl, G., Pantlitschko, M., and Bauer, P. (1973). Serumeisennormalwerte and statistiche verteilung der einzelwerte bei mann und frau. Blut, 27, 261-269.

Willmott, F. E. (1975). Genital yeasts in female patients attending a VD clinic. British Journal of Venereal Diseases, 51, 119-122. 